\title{
EFEKTIFITAS IKLAN NEGATIF DI MEDIA SOSIAL DALAM POLITIK DI INDONESIA
}

\author{
Rully \\ Fakultas Ilmu Sosial Ilmu Politik Universitas Muhammadiyah Tangerang \\ rully@umt.ac.id
}

\begin{abstract}
Political advertising has been part in series of political campaigns with all its dynamics. Interestingly, social media is quite effective attracting voters thus emerging the supporting community. This phenomenon is felt since 2014 Elections, when viewed furthermore, the shared content in socmed has same patterns packing political ads, which plays negative issue in society. How is the effectiveness of political ads through socmed in Indonesian politics? Why is a negative political ads tends to have more influence in society? According Perloff (2014), the feature of political ads is to direct its negativity, used for colorful roles in presidential campaigns and proving that it is easier for people to consider negative advertising than positive advertising. Qualitative descriptive analysis will reveal the phenomena with relevant theories to the effects of socmed illustrating its power to form partisan, volunteer or support community as well as other effects from spreading the issue in society.
\end{abstract}

Keywords: New Media, Campaign, Sosial Media, Negatif Ads, Communication Politic

\section{PENDAHULUAN}

Dalam serangkaian kegiatan politik akan memanfaatkan berbagai media untuk menyampaikan pesan politiknya melalui iklan politik yang bertujuan untuk mendapatkan pengaruh di khalayak. Menurut Kinsey (dalam Mulyana. 2014), iklan politik merupakan senjata berharga bagi para kandidat. Berbagai penelitian mengenai pengaruh iklan politik, bagaimana calon pemilih mengenal kandidat, membantu mereka mengidentifikasikan prioritas dan mempengaruhi standar penilaian mereka dan pemaknaannya. Menurut Kaid (2006) dalam Political Advertising, bahwa iklan politik merupakan alat yang utama dalam pemasaran politik, lebih lanjut Kaid mengatakan, iklan politik telah mendominasi komunikasi antara politisi dan khalayak yang menjadi sasarannya.

Perkembangan teknologi yang begitu cepat secara global mempengaruhi perubahan seluruh tatanan kehidupan di masyarakat. Terlihat dari begitu cepatnya perubahan dalam berkomunikasi, berinteraksi, penggunaan media, ekonomi, maupun komunikasi politik. Dimana media terkini atau dikenal sebagai era media baru menjadi trend sebagai saluran untuk berpolitik. Media baru melalui media sosialnya dengan begitu lincahnya meruntuhkan sekat-sekat dalam komunikasi. Tidak ada lagi filter (saringan) dalam menjadikan media sosial sebagai saluran untuk menyampaikan pesan politik yang juga menjadi salah satu sumber rujukan masyarakat pada saat ini.

Media sosial kini telah berbaur dalam kehidupan sehari-hari di masyarakat. Hampir setiap individu dari masyarakat awam sampai pada politisi memanfaatkan media sosial sebagai sarana untuk saling berinteraksi. Saat ini politisi dan para aktor politik memainkan media sosial untuk menyampaikan segala pesan politiknya, dari sekedar aspirasi, program-programnya, kritik, saran, maupun propaganda yang sampai pada saling tuding di ruang publik. Inilah dinamika politik yang terjadi belakangan ini di Indonesia, sejak 
pilpres 2014 sampai pada pilkada Jakarta kemarin yang belum berakhir hingga detik ini, lihat saja pada media massa yang bertaburan tudingan para politisi.

Media sosial memberikan celah yang lebar untuk keleluasaan ini untuk menjadi wahana politik dalam menyebarkan citra, kampanye, hingga iklan politik yang bermuatan positif ataupun negatif (Black Campaign), yang tentu saja tujuannya ingin menggiring opini di masyarakat. Dalam Perloff (2014), sebuah riset tentang kampanye kongres pada tahun 2002, 2004, dan 2006 menemukan hal negatif meningkat di situs dan iklan televisi (Druckman, Kifer, \& Parkin; 2010).

Munculnya situs-situs yang sarat dengan konten-konten politik merupakan salah satu bukti bahwa media sosial merupakan kanal yang lebar untuk dimanfaat dalam kegiatan politik. Tinggal tugas dari para tim sukses untuk membalut pesan politik menjadi iklan politik sebagai bagian dari strategi politik untuk meraih simpati di masyarakat. Perloff $(2014 ; 340)$, dimana pemasaran adalah konsep luas yang menggambarkan proses mengkomunikasikan dan mendistribusikan produk dan layanan yang bernilai kepada konsumen. Dalam pemasaran komersial, penjual menukar produk tertentu dengan uang dari konsumen. Dalam pemasaran politik, kandidat tersebut memberikan serangkaian janji dengan mengharapkan imbalan suara dari masyarakat yang memilihnya.

Melimpah ruahnya media sosial dengan segala fitur dan kemudahannya menjadikan pesan dapat disampaikan kepada masyarakat melalui iklan-iklan politik, seperti testimoni, jargon politik, yang memunculkan partisipasi masyarakat dengan istilah terkini sebagai 'relawan' bagi yang mendukung dan 'hater' bagi yang tidak mendukung. Namun yang menarik ialah justru iklan politik yang bermuatan negatif malah lebih cepat mendapatkan tanggapan dari masyarakat. "Periklanan-terutama iklan negatif-adalah elemen kunci dalam kampanye politik. Iklan adalah modal utama dimana kandidat berkomunikasi dengan pemilih dalam pemilihan presiden, dan mereka memainkan peran yang meningkat dalam pemilihan di seluruh dunia" (Perloff, 2014; 339).

Hal inilah yang menarik untuk dikaji, apalagi dinamika politik yang terjadi selalu menarik untuk diteliti. Faktanya sekarang di Indonesia, iklan politik telah merambah dalam berbagai media sosial dengan beragam kemasan yang terus-menerus menyebar dan menjadi perdebatan di masyarakat. Yang kemudian menjadi pertanyaan adalah; Bagaimana efektifitas iklan politik melalui media sosial dalam politik di Indonesia? Yang selanjutnya melihat pada realitas di masyarakat sehingga memunculkan premis minor, mengapa iklan politik yang cenderung pada negativitasnya justru berpengaruh di masyarakat?

\section{KAJIAN LITERATUR}

\subsection{Komunikasi Politik, New Media dan Media Sosial}

Berbagai definisi mengenai komunikasi politik. Dalam Subiakto (2012), menurut Lord Windhesham: "Political communication is the liberate passing of a political message by sender to a receiver with with the intention of making the receiver behave in a way that might not other wise done". Sementara Meadow menekankan pada sistem politik, yaitu; "Any exchange of simbol or message that to a significant extent have been shaped by, or have consequences for the function of political system"

Harold Lasswell yang dikenal dengan model komunikasinya, Who Says What in Which Channel to Whom with What Effect, yang menjadi salah satu model komunikasi politik bersifat linear yang dianggap cocok untuk komunikasi massa maupun sebagai landasan komunikasi politik. Sedangkan secara singkat Chaffe (1975) mendefinisikan, komunikasi politik itu dipahami sebagai peran komunikasi dalam proses politik, dan jika dipahami maka proses politik itu luas, maka sudah barang tentu ruang lingkup komunikasi politik pun luas (Heryanto \& Rumaru, 2013:4).

Media kontemporer yang menghiasi peradaban sekarang telah diprediksi oleh Blumler (1995), yang menyadari kemunculan "third age of political communication" adanya pergeseran dari peran media cetak dan 
penyiaran yang tidak lagi menjadi saluran komunikasi politik yang utama jika merujuk pada dinamikanya, antara lain; (1) Generasi pertama, retorika politik (art of speech), (2) Generasi kedua, ditandai dengan dominannya peran media massa atau di kenal sebagai media mainstream,(3) Generasi ketiga, ditandai dengan perkembangan new media.

Dalam New Media: a critical introduction (Lister, dkk; 2009;12), secara komprehensif memecah istilah global 'Media Baru', yang merujuk pada; (1) New textual experiences, (2) New ways of representing the world, (3) New relationships between subjects (users and consumers) and media technologies, (4) New experiences of the relationship between embodiment, identity and community, (5) New conceptions of the biological body's relationship to technological media, (6) New patterns of organisation and production. Yang selanjutnya dalam risetnya berkaitan dengan New ways of distributing and consuming, Computer-mediated communications, Virtual 'realities', dan whole range of transformations and dislocations of established media.

Menurut Gates (2006:419), gagasangagasan tentang jejaring dan interaktivitas telah mendominasi wacana politik kontemporer, dan iklim politik terkini ditandai antara lain oleh obsesi terhadap serangkaian problem teknologi atau keasyikan teknologi, mulai dari produktivitas riset, persaingan teknologi, dan perlindungan kepemilikan intelektual, hingga pemahaman publik atas sains, efek teknologi yang tak terduga, dan kebutuhan akan pelatihan teknik yang berkelanjutan untuk mengantisipasi perubahan teknologi yang pesat (dalam Mulyana, 2014).

Pada era sekarang inilah new media berkembang pesat, melampaui dengan apa yang diharapkan. Media baru melonggarkan pola komunikasi yang tidak lagi 'one to many' melainkan 'many to many', demikian lenturnya media baru saat memudahkan seluruh masyarakat untuk terlibat aktif dalam rangkaian kegiatan politik.

\subsection{Pemasaran Politik dan Iklan Politik}

Pemasaran politik tidak bisa dipisahkan dalam rangkaian kegiatan politik. Idealnya citra seorang kandidat perlu dikonstruksikan untuk membentuk opini dalam masyarakat. Pemasaran politik merupakan konsep yang diintroduksikan dari penyebaran ide-ide sosial di bidang pembangunan dengan meniru cara-cara pemasaran komersial, tetapi orientasinya lebih banyak pada tataran penyadaran, sikap, dan perubahan perilaku untuk untuk menerima hal-hal baru. Cara penyebaran seperti ini dilihat dari konteks dan orientasi disebut "pemasaran sosial" yang secara substantif tidak jauh berbeda dengan istilah penyuluhan, sosialisasi, dan kampanye (Cangara, 2009; 276).

Menurut Moriarty $(2011 ; 6)$ dalam bukunya, Advertising adalah jenis komunikasi pemasaran, yang secara umum mengacu kepada semua bentuk teknik komunikasi yang digunakan pemasar untuk menjangkau konsumennya dalam menyampaikan pesannya. Advertising sebagai sesuatu yang kompleks namun dalam satu hal advertising itu sederhana, didalamnya terdapat penciptaan pesan dan mengirimkannya kepada orang dengan harapan orang itu akan bereaksi dengan cara tertentu. Iklan adalah pesan yang kebanyakan dikirim melalui media dan ukuran efektifitas jika konsumen bereaksi sesuai pesan yang disampaikan dalam iklan.

Hopkins dalam bukunya Scientific Advertising (1923) mengatakan, iklan telah menjadi ilmu tersendiri dan efek yang dapat dianalisis untuk capaian yang efektif. Di bukunya juga membahas psikologi, seni dalam iklan, serta membahas tentang iklan yang negatif. Menurutnya, beriklan tidak sepenuhnya intuitif, karena nyatanya banyak menerapkan kaidah-kaidah ilmu sosial serta memperkirakan dan mencoba mempengaruhi perilaku konsumen (Rivers, 2003; 271)

\subsection{Net Generation sebagai partisipasi politik.}

Jika sebelumnya kesadaran individu pada politik dikatakan sebagai partisipasi politik kini dengan adanya media sosial kesadaran individu terhadap politik menjadi semakin cepat. Kaid \& Haltz-Bach (dalam 
Subiakto, 2012), partisipasi politik diartikan sebagai aktivitas warga negara yang bertujuan memengaruhi kebijakan politik.

Menurut Carr (2010), mereka para pengguna media sosial memiliki kecenderungan akan budaya baru atau disebut scroll culture. Media baru telah menjadi perubahan besar dalam penggunaan media, interaksi dan berkomunikasi. Segala aktivitas komunikasi lebih banyak dilakukan dan dikendalikan oleh scrolling jari dengan ragam fitur yang di dalamnya, sehingga segala aktivitas komunikasi menjadi lebih instan, dan dapat dilakukan bersamaan (multi tasking activities). Seorang ahli digital Don Tapscott (2009) yang telah melakukan banyak riset dalam bukunya Grown up Digital mengemukakan bahwa generasi internet dan karakteristiknya sebagai generasi global yang tumbuh bersama internet dan media sosial. Dengan perubahan global tersebut, mereka tumbuh peduli terhadap lingkungan, isu-isu yang sedang terjadi, sosial maupun politik, bahkan menampilkan dirinya sebagai relawan atau pun sebaliknya.

Dalam 'What is Social Media', Antony Mayfield (2008) mendefinisikan media sosial sebagai suatu kelompok jenis baru media yang mencakup beberapa karakter, seperti; (1) Partisipasi, (2) Keterbukaan, (3) Percakapan, (4) Komunitas, (5) Saling Terhubung. Karakteristik inilah yang mendukung pendapat Matthew A. Baum \& Tim Groelling mengemukakan bahwa para pengguna media sosial berpotensi menjadi opinion leader baru yang akan mendapatkan pengikutnya masing-masing (dalam Shahreza, 2016;163)

\subsection{Karakteristik Iklan Politik.}

Iklan politik didefinisikan dalam Cangara (2009), "Political Advertising refer to the purchase and use of advertising space, paid for commercial rates, in order to transmit political messages to a mass audience". Iklan politik mengacu pada ruang atau media untuk menyampaikan pesan politiknya kepada khalayak.

Telah sejak lama iklan politik memainkan peran yang penuh warna dalam kampanye presiden, sejak iklan politik pertama di televisi 1952 dan kini telah berevolusi. Karakteristik iklan politik (Perloff, 2014), antara lain; Pertama, iklan politik didanai oleh kelompok politik luar, Kedua, saat ini iklan politik lebih banyak menghasilkan uang dibandingkan sebelumnya, Ketiga, iklan politik lebih kepada negatifitasnya, Keempat, iklan politik cenderung memiliki nilai produksi yang tinggi layaknya sinematografi yang mengunakan gambar, musik untuk menciptakan suasana hati. Kemudian seiring perubahan, karakteristik, Kelima dari iklan politik kontemporer, pembelian jam tayang serta penekanan pada teknologi konvensional dan interaktif.

Dalam pemasaran politik, setiap kandidat tersebut memberikan serangkaian janji dengan imbalan suara pemilih (Perloff, 2014: 340). Newman (1994: 9) menjelaskan, "Kandidat tersebut pada kenyataannya adalah penyedia layanan dan menawarkan layanan pada konsumennya, para pemilih, sama seperti agen asuransi yang menawarkan layanan kepada konsumennya.....dalam lingkungan yang dinamis, cepat, berubah, penuh hambatan dan tantangan pemasaran sehingga memerlukan fleksibilitas"

Albert Frey (dalam Rivers, 2003;271), menulis tentang empat jenis bujukan, yaitu: Bujukan primer: dimaksudkan agar konsumen membeli satu jenis produk tertentu. Bujukan selektif: agar konsumen membeli merek tertentu. Bujukan emosional: menggugah emosi konsumen agar membeli sesuatu. Bujukan rasional: agar konsumen mau berpikir dalam memilih suatu produk.

Dari aspek politik modern menghasilkan banyak kritik terhadap iklan negatif, iklan negatif dan segala kebrutalannya dalam memperdagangkan hinaan sejak pemilihan presiden Amerika yang paling awal. Namun iklan negatif mampu menjangkau lebih banyak orang. Bagaimana hal tersebut bisa terjadi? Ada bukti empiris yang menjelaskan, salah satunya bahwa iklan negatif secara psikologis lebih mudah diingat dan memiliki efek yang lebih kuat sehingga memunculkan tanggapan.

\subsection{Iklan Negatif}


Beberapa aspek politik modern menghasilkan sejumlah kritik terhadap iklan negatif. Bahkan sejak pemilihan Amerika yang paling awal kandidat politik telah memperdagangkan hinaan secara brutal, yang melibat keluarga, dan skandal lainnya (Perloff, 2014; 347). Jill Buckley, seorang konsultan Demokrat menjelaskan, "Orang bilang membenci iklan negatif, tetapi itulah bentuk keberhasilan, karena membencinya bersamaan dengan mengingatnya" (JohnsonCartee \& Copeland, 1991;5)

Sejak tahun 1950an iklan negatif telah meningkat secara drastis dan banyak jenis negativitas iklan politik, termasuk dalamnya (1) Gaya atau gestur ketika seorang kandidat berbicara langsung menghadap kamera, (2) Testimoni dari pembicara seorang yang kredibel atau menentang kandidat politik, dan (3) Melalui iklan menjelaskan tentang apa yang dilakukannya. Walaupun iklan tersebut bisa bermuatan positif ataupun negatif melalui beragam cara untuk menarik perhatian, seperti membandingkan atau menyerang langsung pada karakter kandidat lain (Perloff, 2014;342).

\subsection{Efek Iklan Negatif, Persuasi dan Opini Publik}

Secara empiris dalam Perloff (2014; 348), membuktikan iklan negatif lebih mudah untuk dikenali dan diingat dibandingkan iklan positif (Newhagen \& Reeves, 1991; Shapiro \& Rieger, 1992). Ada psikologis didalamnya dan memberikan dampak yang kuat dari tayangan iklan negatif. Informasi negatif memunculkan tanggapan yang lebih kuat dan lebih cepat daripada informasi positif (O'Keefe, 2012).

Nimmo (2011) mengemukan persuasi politik memiliki tiga pendekatan, yaitu; progaganda, periklanan, dan retorika. Ketiganya memiliki karakteristik yang serupa, yakni memiliki tujuan yang sama, melibatkan pengaruh, dan direncanakan untuk mempengaruhi persepsi dan opini khalayak. Propaganda disebut putih, abu-abu atau hitam, tergantung pada properti yang atribut sumber (Littlejohn, 2016;968). Ada pun tujuh teknik propaganda yang telah lama dikenal
(Cangara, 2009), antara lain sebagai berikut; (1) Memberi Julukan (name calling), (2) Gemerlap (glittering generalities), (3) Pengalihan (transfer), (4) Pengakuan (testimonial), (5) Plain Folks, (6) Pengikut (bandwagon), (7) Memakai Fakta (card stacking), (8) Kecurigaan yang penuh emosi (emotional stereotype), (9) Retorika.

Menurut Devlin (dalam Perloff, 2014), meskipun efek iklan politik rumit, namun konsultan politik percaya bahwa titiktitik negatif dapat mempengaruhi hasil suara pemilih. Lebih lanjut pada bagian tersebut menjelaskan efek-efek yang terjadi dalam iklan politik seperti; efek hipodermik, konsep agenda seting dan priming, Framing, yang mempengaruhi dan memunculkan partisipan politik, yang memunculkan priming dimasyarakat. Namun efek iklan politik berbanding sebaliknya dengan pengetahuan khalayak mengenai partai ataupun kandidatnya. sehingga apa yang telah terbentuk dalam benak khalayak sulit untuk dirubah (McNair, 2011).Sehingga jika diakumulasikan priming yang terjadi dalam masyarakat memberikan bukti bahwa pesan politik telah dapat tersampaikan dengan munculnya ragam opini yang berkembang diruang sosial masyarakat, dimana faktanya hampir setiap sudut ruang sosial membicarakan dan memperdebatkan apapun yang berkaitan dengan politik.

\section{METODE PENELITIAN}

Kajian ini menganalisa terkait dengan iklan politik di media sosial sebagai strategi politik di Indonesia serta menjawab asumsi bahwa iklan politik merupakan bagian dari strategi politik melalui media kontemporer (media sosial) sebagai refleksi dari dinamika politik saat ini. Melalui pendekatan kualitatif berdasarkan literatur teori-teori yang dianggap relevan, mengamati keadaan sosial untuk kemudian menyimpulkan secara deskriptif, sehingga mampu menjawab premis tentang efektifitas iklan politik melalui media sosial serta kecenderungan pada negativitasnya justru berpengaruh, yang merupakan dampak yang terjadi di masyarakat. 
Selain itu juga mengamati aktivitas di media sosial seperti facebook, twitter maupun situs di internet. Juga melibatkan diri secara langsung dalam komunitas relawan dan mengamati percakapan di group-group politik relawan hingga data yang didapat dari hasil wawancara dari para narasumber yang relevan. Denzin dan Lincoln (dalam Moleong, 2014) menyatakan bahwa penelitian kualitatif menggunakan latar alamiah, dengan maksud menafsirkan fenomena yang terjadi dan dilakukan dengan jalan melibatkan berbagai metode yang ada.

\section{HASIL DAN PEMBAHASAN}

Sejarah politik dunia mencatat kontribusi online terhadap keberhasilan Obama menjadi presiden Amerika Serikat. Dalam catatan Whilock (1997), kampanye Bill Clinton pada tahun 1992 menjadi kampanye politik pertama yang menyebarkan teks pidatonya lewat internet. Dalam artikel resensi buku Communicator-in-Chief: How Barack Obama Used New Media Technology to Win the White House oleh Jarvis (2010), disebutkan bahwa situs untuk kampanye Obama mengorganisasikan lebih dari seratus lima puluh ribu kegiatan, menciptakan lebih dari tiga puluh lima ribu kelompok, memiliki lebih dari 1,5 juta akun dan mendapatkan lebih dari USD 600 juta dari 3 juta donor. Dalam kampanye tersebut menggunakan youtube untuk iklan gratis, mengirimkan alamat iklan atau tautan kepada para pendukung, dan membroadcast-nya lagi. Akun facebook Obama mempunyai $52,777,503$ pendukung, dari situs yang diakses (https://www. facebook.com/barackobama).

Saat ini pun para politisi di Indonesia aktif di media sosial seperti facebook, twitter atau melalui situs pribadinya. Media sosial seperti facebook dan twitter masih menjadi pilihan utama hingga saat ini. Sebagai contoh, pada akun twitter presiden sebelumnya, Susilo Bambang Yudhoyono yang telah memiliki sebanyak $9.77 \mathrm{M}$ pengikut (https://twitter.com/SBYudhoyono). Beberapa politisi yang aktif memainkan media sosial twitter, antara lain; Budiman Sudjatmiko (@budimandjatmiko) yang memiliki pengikut $584 \mathrm{~K}$ dan $159 \mathrm{~K}$ tweets, Fahri Hamzah (@fahrihamzah) dengan 536 ribu pengikut dan $56.7 \mathrm{~K}$ tweets, sampai pada Jokowi (@jokowi) yang memiliki 8.1M pengikut dan 749 tweets.

Melihat lebih jauh pada akun-akun tersebut dan atau para politisi lainnya akan terlihat sangat banyak komentar bahkan tudingan yang menghiasinya, terlepas dari konten yang dikemukakan dalam akun tersebut. Ruang perdebatan sangat melekat dalam media sosial, jika melihat pada jumlah pendukungnya, bisa dilihat potensi dan kemungkinan yang terjadi, selain sebagai wadah pencitraan, propaganda politisi, penggiringan opini, sampai pada pertengkaran diruang publik.

Sekarang, petisi telah muncul dalam media sosial, bahkan dengan adanya mediamedia sosial masyarakat dapat langsung membawa-bawa (mention) tokoh maupun politisi tersebut untuk mengungkapkan responnya. Atau melihat pada aksi-aksi massa yang begitu marak dan mudahnya untuk berperan dalam setiap isu nasional maupun isu politik. Yang rasanya tidak akan mungkin terjadi jika hanya melalui media massa konvensional sebagai sarana informasi dan komunikasi. Disinilah media sosial turut berperan dalam percepatan penyebaran informasi.

Pilpres 2014 yang berlanjut pada pilkada Jakarta istilah relawan muncul sebagai partisipan politik. Beberapa komunitas seperti Projo, Seknas, BaraJP, Pospera, GK (Galang Kemenangan), dan masih banyak lagi pada jaringan komunitaskomunitas kecil yang bermunculan menambah semarak demokrasi di Indonesia. Bahkan pada Juli 2017 telah mengadakan Silahturahmi Nasional (Silatnas) kedua, sebagai bentuk dukungan dari para relawan. Serupa juga komunitas pendukung atau relawan muncul dalam pilkada Jakarta. Teman Ahok, Relawan Cinta Ahok, Ahok Fans Club, Barisan Independen Ahok, dan masih banyak lagi yang lainnya, sampai pada aksi 1000 lilin sebagai bentuk dukungan terhadap kasus yang menimpa Basuki Tjahaja Purnama. 
Namun tidak hanya dukungan, yang mendukung atau kelompok-kelompok yang berseberangan pun sangat terasa sejak pilpres 2014. Di media sosial terasa sekali pertarungan antara yang pro dan kontra sampai saat ini. Menariknya perdebatan itu menampilkan data, gambar, atau 'meme' hingga menyebarluas. Terlepas dari mana sumber data tersebut, namun yang menarik adalah mengapa begitu banyak munculnya media online dan menjadi rujukan para partisipan politik? Akibatnya saling mempertahankan pendapat berdasarkan sumber-sumber yang masing-masing menyakini kebenarannya. Jelas, bahwa tidak semua media online dapat diyakini kebenarannya, karena etika jurnalis dan undang-undang Pers telah mengatur bagaimana bermedia dan etika dalam menampilkan suatu berita.

Mengapa gerakan yang skalanya cukup besar dengan mudahnya terjadi, terlepas dari konteks aksinya, namun masingmasing kubu dengan mudahnya untuk digerakkan. Penggalangan aksi, pengalangan dana, menghiasi pemberitaan di media massa. Apakah media sosial yang sangat efektif untuk penyampaian pesan dari iklan politik dalam menjaring simpatisan? Atau para penggiat media sosial yang mampu menjadi Opinion Leader, seperti ungkapan Matthew A. Baum \& Tim Groelling, bahwa para pengguna media sosial berpotensi menjadi opinion leader baru yang akan mendapatkan pengikutnya masing-masing.

Dalam riset yang meneliti penggunaan sosial media dan internet, lebih dari 80 persen penggunanya berusia 18 sampai 29 tahun dan 72 persen dari jumlah tersebut menggunakan media sosial (Lenhart et al., 2010). Sehingga peluang inilah yang dimanfaat para politisi dan para pelaku politik yang terlibat didalamnya untuk mampu menjangkau audiennya, dan faktanya di Indonesia pada usia-usia tersebut gadget atau alat komunikasi dalam genggamannya lebih menarik daripada televisi.

Lihat saja pada timeline di media sosial yang sampai memunculkan komentar untuk menanggapi apapun dan siapapun. Bahkan status seseorang seperti saling bersahutan, di twittwer akan saling mention antar politisi, tokoh masyarakat, atau istilahnya di kenal dengan 'twittwar' yang seringkali masyarakat terlibat didalamnya, baik pendukung atau bukan pendukungnya. Tak jarang perang status di media sosial memunculkan hashtag (\#) yang menjadi pembicaran trending topic di skala nasional maupun skala internasional.

Seperti \#Jokowi9Juli, status dukungan Sting terhadap Jokowi itu mendapat 'jempol' (like) atau disukai sebanyak 17.531 pengguna Facebook. Ada 4.905 komentar dan 7.868 yang dibagikan lagi ke halaman facebook mereka atau kepada yang lainnya. Jason Mraz melalui akun twitternya, @jason_mraz yang diikuti 5 juta. Atau Arkarna dengan kicauannya "VOTE JOKOWI NOW FOR A BETTER AND STRONGER FUTURE FOR INDONESIA! EVERY VOTE COUNTS GUYS!\#ArkarnaVoteJokowi-retweet!"

demikian tulis Arkarna lewat akun Twitternya @ arkarna, telah respon kembali sebanyak 26 ribu. Contoh lainnya, masih ingat dengan (hastag) \#AkhirnyamilihJokowi atau \#DariAwalMilihJokowi?

Inilah dinamika politik yang sekarang terjadi dan berbeda di bandingkan periodeperiode sebelumnya. Sekilas terasa sekali antusiasnya masyarakat dalam politik. Segala isu politik selalu menarik untuk dibicarakan dari warung kopi pinggir jalan sampai pada forum-forum resmi. Tidak ada lagi batas dan sekat antar masyarakat untuk berpartipasi dalam politik. Media sosial menjadi ruang publik yang baru untuk ini semua, siapa pun bisa bebas mengeluarkan opini dan berpendapat, dan siapa pun berhak untuk bersikap menyetujui atau tidak.

Catatan dari sumber berita online tribunnews.com yang mengumpulkan perihal berita iklan politik dalam tautan (http:// www.tribunnews.com/tag/iklan-politik), yang memberitakan sulitnya menindak pelanggaran pada iklan politik, keresahan masyarakat akan frekuensi publik tentang iklan kampanye, Iklan politik yang harus dibatasi, serta penolakan-penolakan dari parpol tentang moratorium iklan. Dari situs kompas.com dalam tautan (http://nasional.kompas.com /read/2014/03/14/1229524/Ini.10.Partai.yang 
.Melanggar.Aturan.Iklan.Kampanye), yang mengemukakan temuan tentang iklan politik di TV. Dalam paparannya, selama periode 1 Maret - 11 Maret 2014 tayangan iklan kampanye tersebut dengan rincian; Partai Golkar (487 spot iklan), Partai Nasdem (387 spot iklan), Partai Gerinda (305 spot iklan), PDI-P (273 spot iklan), PKB (90 spot iklan), Partai Hanura (80 spot iklan), PAN (67 spot iklan), PKPI (42 spot iklan), PKS (9 spot Iklan), Partai Demokrat (8 spot iklan).

Sekilas data diatas memperlihatkan iklan politik merupakan senjata utama bagi kandidat. Melalui berbagai cara, melibatkan suatu proses yang membutuhkan dana yang besar seperti memasarkan suatu produk, diolah serius, yang secara terus-menerus muncul di TV untuk menggiring opini dan meraih simpati masyarakat. Dan seiring perkembangannya, iklan-iklan politik tidak hanya muncul di layar kaca dan melibatkan para kandidat saja, namun beranjak memenuhi ruang-ruang di media sosial yang begitu cair, muncul dan menyebar di internet dalam situs Youtube, Facebook, Twitter, sampai pada percakapan di WhatsApp. Menyebar kemana saja bak bola liar bersamaan dengan menjamurnya buzzer politik.

Fenomena ini mulai marak di Indonesia sejak 1990-an, sedangkan di Barat dan Asia telah dimulai sejak 1980-an. Kini komunikasi politik kian menarik di Indonesia, pergeseran dari media massa ke media baru memberikan dinamika tersendiri tanpa menghilangkan 'ruh' dari kampanye politik. Media sosial seperti Facebook, Twitter, Website, masih menjadi pilihan pada saat ini. Dimana penggunaan Facebook dan Twitter masih menjadi media sosial dengan jumlah penggunaan yang tertinggi di Indonesia, bahkan di dunia. Disamping itu facebook, Twitter, dan Website memiliki perbedaan dan kelebihan masing-masing. Sehingga kerap kali digunakan bersamaan dalam politik, sebagai saluran komunikasi politik.

Menarik dengan apa yang diungkapkan Nimmo, 'Kebanyakan politisi mendapat kesulitan besar untuk bisa dikenal bahkan untuk mempunyai citra'. Mungkin karena itu pulalah maka berbagai upaya dilakukan politisi untuk memperoleh citra positif tetapi dengan dan atau tanpa disadari menggiringnya kearah pembentukan citra yang justru negatif (Arrianie, 2010: 18).

Terlihat bahwa media sosial kian digandrungi dan menjadi media dalam menyampaikan pesan bagi para politisi. Angka-angka pengikut dan jumlah tweet memberikan gambaran sederhana bagaimana 'who' sangat mempengaruhi suatu pesan yang akan dimaknai masyarakat dan tentu saja berpeluang untuk pemaknaan berbeda dan kemudian menjadi viral di masyarakat yang dapat menjadi sumber konflik. Hanya saja pengaruh 'who' formulasi Lasswell dalam konteks ini menjadi sumber bias dalam masyarakat. Pola komunikasi dari media baru yang menganut 'Many to many' memberikan percepatan yang luar biasa dalam mempengaruhi khalayak.

Beberapa faktor yang turut menunjang penggunaan internet dalam politik di Indonesia, antara lain; Pertama, sistem politik yang kian berjalan demokratis, Kedua, semakin majunya teknologi komunikasi dan Informasi, era konvergensi media yang memudahkan untuk berkomunikasi. Ketiga, tingginya tingkat pengguna media sosial di Indonesia.

Indonesia tercatat sebagai negara yang paling 'terhubung' di dunia dengan pengguna facebook diatas 88 juta pada tahun 2016 yang sebelumnya 41 juta pada tahun 2010. Sedangkan pengguna twitter pada 2010 sebesar 4,8juta dan terbesar keempat di dunia. Angka-angka diatas memberikan gambaran tingginya antusias masyarakat Indonesia dalam menyambut era media baru, menyambut kebebasan ekspresi di ruang publik yang baru (new public sphere) dengan segala kekurangan infrastruktur dan masih jauhnya tingkat kecepatan akses internet di Asia menurut situs internetworldstats.

Dapat dikatakan di media sosial partisipasi politik semakin berkembang, dan publik tidak lagi menjadi audien yang pasif. Seringkali audien dapat memproduksi ataupun mereproduksi pesan politik dan mengekspresikan opini dari perspektifnya. Terlebih saat ini publik mememiliki kebebasan yang seringkali kebablasan. Dari 
sinilah benih konflik dapat bermunculan yang membutuhkan peran lebih dari semua pihak untuk meredam segala kemungkinan membesarnya suatu konflik dalam kehidupan masyarakat.

Roberts, 1997 (dalam Arifin, 2008) menyatakan bahwa komunikasi tidak secara langsung menimbulkan pendapat atau perilaku tertentu, tetapi cenderung mempengaruhi cara khalayak dalam mengorganisasikan citranya tentang lingkungan dan citra itulah yang mempengaruhi pendapat atau perilaku publik. Menurut Schoeder (2004), internet adalah suatu ruang publik dimana orang-orang menggunakannya untuk membaca dan mengekspresikan opini-opini politik mereka. Karena itu internet menghubungkan politisi, partisan partai-partai politik, aktivitis, dan organisi non-partai.

Sehingga lumrah jika saat ini kegiatan politik beserta seluruh elemennya menggunakan media sosial dalam kesehariannya. Baik untuk penggunaan pribadi atau partai-partai politik yang saling berebut kekuasaan, maupun bermotif untuk membangun citra di masyarakat. Nimmo mengatakan seorang kandidat semestinya menawarkan diri dalam merek berbeda, namun tetap dalam produk yang sama. Memiliki tujuan yang sama untuk mendapatkan respon dari calon pemilih, sehingga pada prakteknya seringkali iklan politik cenderung negatif, seperti menyerang kandidat lain, meninggikan citra, atau menawarkan ide dan program yang berlebihan.

Masyarakat baik individu atau pun para sekelompok relawan juga turut aktif membangun iklan politik secara spontan dan menyebarluaskan kembali kepada siapa saja melalui media sosial, termasuk memproduksi dan mereproduksi pesan di media sosialnya dengan variasi konten, dikarenakan media sosial mampu mewadahinya. Oleh sebab itu, iklan politik memiliki agenda menggunakan isu-isu yang mudah untuk 'dimainkan' dalam masyarakat. Tentunya dalam mengemasnya telah melalui segala macam proses yang mempertimbangkan unsur-unsur demografi masyarakat dengan tujuan akhir untuk mendapatkan suara dari masyarakat, sehingga efektifivas dapat diukur ketika pesan tersebut sampai pada masyarakat yang tidak hanya dinilai positif, namun perdebatan dan opini yang berkembang dimasyarakat turut mempengaruhi efektivitas tersebut.

\section{KESIMPULAN}

Media sosial sebagai saluran komunikasi politik sederhananya dapat dikatakan sebagai alat, wadah, kanal, ruang atau sarana dalam menyampaikan pesan, "maka saluran komunikasi itu lebih daripada sekedar titik sambungan, tetapi terdiri atas pengertian bersama tentang siapa dapat berbicara kepada siapa, mengenai apa, dalam keadaan bagaimana, sejauh mana dapatnya dipercaya" (Nimmo, 2011;167). Sehingga pada saat ini media sosial merupakan sarana yang efektif dan efesien untuk media berpolitik, selain keleluasaannya juga fiturnya yang mewadahi teks, audio, dan visual.

Sekat tanpa batas yang dimiliki oleh media sosial juga turut melonggarkan komunikasi, percepatannya yang mampu menjangkau masyarakat dan menciptakan ragam opini di masyarakat yang kemudian menumbuhkan pastipasi masyarakat untuk terlibat langsung dalam politik. Namun Pengaruh globalisasi disatu sisi ternyata menimbulkan pengaruh yang negatif bagi kebudayaan bangsa Indonesia. Lebih lanjut dalam jurnal Surahman (2016), Gencarnya serbuan teknologi disertai nilai-nilai interinsik yang diberlakukan di dalamnya, telah menimbulkan isu mengenai globalisasi yang mengikis nilai-nilai yang terkandung dalam masyarakat Indonesia.

Senada dengan pandangan Pierre Lexy yang menulis buku terkenal Cyberculture. Lexy memandang World Wide Web sebagai sebuah lingkungan informasi yang terbuka, fleksibel dan dinamis, yang memungkinkan manusia mengembangkan orientasi pengetahuan yang baru dan juga terlibat dalam dunia demokratis tentang pembagian mutual dan pemberian kuasa yang lebih interaktif dan berdasarkan pada masyarakat (dalam Littlejohn, 2009: 413).

Kritik dan dukungan terhadap kandidat merupakan efek dari pesan politik yang 
sampaikan. Termasuk cara dan tema yang diangkat dalam iklan politik merupakan simbol dan gestur juga mampu merangsang pemikiran masyarakat. Sebagaimana menurut Schudson (dalam Perloff; 2014), bahwa periklanan negatif adalah jenis komunikasi persuasif yang kompleks, multi segi, dan membuat ketidak nyamanan.

Iklan negatif juga memiliki sisi positifnya, antara lain; berfokus pada pada isu yang terjadi sehingga menjadi koreksi di masyarakat, membuat masyarakat untuk lebih aktif dalam proses politik serta mendorong aktivis politik untuk lebih berperan aktif dalam politik. Namun kembali pada masyarakat dan lingkungan sosialnya dalam memaknai suatu pesan dalam setiap iklan politik.

\section{REFERENSI}

Arrianie, Lely., 2010. Komunikasi Politik: Politisi dan Pencitraan di Panggung Politik. Widya Padjadjaran.

Blumler, Jay G., Michael Gurevitch. 1995. The Crisis of Public Communication. New York: Routledge.

Cangara, Hafied., 2009. Komunikasi Politik: Konsep, Teori, dan Strategi, Jakarta: Rajawali Pers.

Carr, Nicholas. 2010. The Shallows: What the Internet Is Doing to Our Brains. New York: W. W. Norton \& Company, Inc.

Gates, Kelly. 2006. "Identifying the 9/11 'Face of Terror': The Promise and Problem of Facial Recognition Technology." Cultural Studies 20.4-5, hlm 417-440.

Hendricks, John Allen., Robert E. Denton Jr. (editors). 2010. Communicator-inchief: how Barack Obama used new media technology to win the White House. Lexington Books

Heryanto, Gun Gun., Shulhan Rumaru. 2013. Komunikasi Politik: Sebuah Pengantar. Bogor: Ghalia Indonesia.

Kaid, Lynda Lee., Christina Holtz-Bacha. 2006. The Sage Handbook of Political Advertising. Califonia: Sage Publications, Inc.
Lenhart, Amanda., Kristen Purcell., Aaron Smith., Kathryn Zickuhr. 2010. Social Media \& Mobile Internet Use Among Teens and Young Adults. Pew

Research Center.

Lister, Martin., Jon Dovey, Seth Giddings, Iain Grant and Kieran Kelly. 2009. New Media: a critical introduction. New York: Routledge.

LittleJohn, Stephen W., Karen A. Foss. 2008. Theories of Human Communication. Wadsworth. California. Ninth Edition.

LittleJohn, Stephen W., Karen A. Foss. 2016. Ensiklopedia Teori Komunikasi. Jakarta: California. Kencana.

Mayfield, Antony. 2008. What is Social Media. iCrossing.

McNair, Brian. 2011. An Introduction To Political Communication. New York: Routledge.

Moleong, Lexy, J., 2014. Metodologi penelitian Kualitatif. Bandung: PT. Remaja Rosdakarya.

Moriarty, Sandra., Nancy Mitchell., Williams Wells. 2011. Advertising. Jakarta: Prenada Media Group.

Mulyana, Deddy. 2014. Komunikasi Politik Politik Komunikasi: Membedah Visi dan Gaya Komunikasi Praktisi Politik. Bandung: PT. Remaja Rosdakarya.

Newman, Bruce I. 1994. The Marketing of The President: Political Marketing as Campaign Strategy. California: Sage Publications.

Nimmo, Dan. 2011. Komunikasi Politik: Komunikator, Pesan, dan Media. Bandung: PT. Remaja Rosdakarya.

Perloff, Richard M., 2014. The Dinamics of Political Communication: Media and Politics in a Digital Age. New York: Routledge.

Rivers, William, L., Theodore Peterson., Jay W. Jensen. 2003. Media Massa dan Masyarakat Modern. Jakarta: Prenada Media.

Shahreza, Mirza., Korry El-Yana., 2016. Etika Komunikasi Politik. Indigo Media. 
Subiakto, Henry., Rachmah Ida. 2012. Komunikasi Politik, Media, dan Demokrasi, Jakarta: Kencana Prenada Media Group.

Surahman, Sigit. 2016. Dampak Globalisasi Media Terhadap Seni dan Budaya Indonesia.

Tapscott, Don. 2009. Grown Up Digital: How The Net Generation is Changing Your World. The McGraw-Hill Companies, Inc.

\section{Sumber Online}

http://www.beritasatu.com/aktualitas/38633417-komunitas-masyarakat-deklarasikanrelawan-cinta-ahok.html

https://news.detik.com/berita/d3596246/pendukung-jokowi-di-silatnas-iidua-periode

http://nasional.kompas.com/read/2017/08/11/ 21304541/silaturahmi-nasional-ii-relawansepakat-dukung-jokowi-dua-periode

http://tv.liputan6.com/read/2950589/aksi1000-lilin-untuk-ahok-di-berbagai-kota

http://www.internetworldstats.com/stats3.htm
https://twitter.com/SBYudhoyono

$\underline{\text { https://twitter.com/budimandjatmiko }}$

$\underline{\text { https://twitter.com/Fahrihamzah }}$

https://twitter.com/jokowi

http://www.tribunnews.com/tag/iklan-politik

http://nasional.kompas.com/read/2014/03/14/

1229524/Ini.10.Partai.yang.Melanggar

.Aturan.Iklan.Kampanye

https://www.jpnn.com/news/sting-tulis-statusdi-facebook-untuk-dukung-jokowi

https://www.facebook.com/sting/posts/10152 $\underline{260232475292 \text { ?fref }=\mathrm{nf}}$

https://news.detik.com/berita/2630659/wowsting-ajak-penggemarnya-di-indonesiadukung-jokowi

https://news.detik.com/berita/2630667/takhanya-sting-jason-mraz-dan-arkarna-jugaberi-dukungan-untuk-jokowi https://twitter.com/hashtag/AkhirnyaMilihJok owi?src=hash

https://twitter.com/search?q=\%23DariAwalM ilihJokowi \&src=typd 